Int. J. Electrochem. Sci., 14 (2019) $11212-11224$

International Journal of

ELECTROCHEMICAL

SCIENCE

WWW.electrochemsci.org

\title{
New Electrochemical Immunosensor of Au/Holey Graphene Oxide and Au/ZnO for Sensitive Detection of Carcinoembryonic Antigen
}

\author{
Aihua Jing ${ }^{1}$, Qiong $\mathrm{Xu}^{1}$, Wenpo Feng ${ }^{1}, \mathrm{Yu}_{\mathrm{Li}}{ }^{1}$ and Gaofeng Liang, ${ }^{2, *}$ \\ ${ }^{1}$ School of Medical Technology and Engineering, Henan University of Science and Technology, \\ Luoyang 471003, P. R. China \\ ${ }^{2}$ Medical college, Henan University of Science and Technology, Luoyang 471003, P. R. China \\ *E-mail: 1gfeng990448@ haust.edu.cn
}

doi: $10.20964 / 2019.12 .29$

Received: 1 August 2019 / Accepted: 19 September 2019 / Published: 29 October 2019

\begin{abstract}
A sandwich-type electrochemical immunosensor was developed using $\mathrm{Au} / \mathrm{ZnO}$ as a nonenzymatic label for the ultrasensitive detection of a tumour biomarker carcinoembryonic antigen (CEA). Au nanoparticle-decorated holey graphene oxide (Au/HGO) was synthesized according a simple hydrothermal procedure and modified on an electrode to have enhanced conductivity, large surfaces areas and good adsorption of immobilizing antibodies ( $\left.\mathrm{Ab}_{1}\right)$. Subsequently, horseradish-peroxidase (HRP)-functionalized $\mathrm{Au} / \mathrm{ZnO}\left(\mathrm{Ab}_{2} / \mathrm{HRP}-\mathrm{Au} / \mathrm{ZnO}\right)$ was fabricated to label the secondary antibodies $\left(\mathrm{Ab}_{2}\right)$. The $\mathrm{Ab} \mathrm{b}_{2} / \mathrm{HRP}-\mathrm{Au} / \mathrm{ZnO}$ catalysed the reduction of $\mathrm{H}_{2} \mathrm{O}_{2}$ in the sandwich-type immunoreactions. An enhanced sensitivity was obtained. Moreover, the proposed immunosensor showed a wide linear range from $0.001 \mathrm{ng} / \mathrm{mL}$ to $100 \mathrm{ng} / \mathrm{mL}$ with a detection limit of $0.6 \mathrm{pg} / \mathrm{mL} \quad(\mathrm{S} / \mathrm{N}=3)$ under the optimal experimental conditions. The disposable immunosensor has high sensitivity, longterm stability, and has clinical value in cancer screening and in appropriate point of care diagnostics.
\end{abstract}

Keywords: $\mathrm{Au}$ nanoparticle/holey graphene oxide; $\mathrm{Au} / \mathrm{ZnO}$; signal amplification; sandwich-type electrochemical immunosensor

\section{FULL TEXT}

(C) 2019 The Authors. Published by ESG (www.electrochemsci.org). This article is an open access article distributed under the terms and conditions of the Creative Commons Attribution license (http://creativecommons.org/licenses/by/4.0/). 